\title{
PENINGKATKAN HASIL BELAJAR INSTALASI JARINGAN MENGGUNAKANMODEL PEMBELAJARAN KOOPERATIF STUDENT FACILITATOR AND EXPLAINING (SFAE)
}

\author{
Sirwan $^{1}$ \\ Teknik Informatika, Universitas Nani Bili Nusantara \\ ${ }^{1}$ Sirwan@unbn. ac.id
}

\begin{abstract}
Penelitian ini adalah penelitian tindakan kelas (Classroom Action Research), bertujuan untuk meningkatkan hasil belajar siswa pada mata pelajaran instalasi jaringan komputer menggunakan Model Pembelajaran Kooperatif Student Facilitator and eksplaining (SFAE). Lokasi Penelitiaan dilakukan di SMK Negeri 8 Jeneponto dengan jumlah subjek sebanyak 30 orang siswa. Teknik Pengumpulan data yang digunakan adalah tes akhir setiap siklus dan lembar observasi untuk Ranah Afektif dan Psikomotorik. Data dianalisis secara kualitatif dan kuantitatif menggunakan UJI Gain. Hasil penerapan Model Pembelajaran Kooperatif Student Facilitator and eksplaining (SFAE) dilaksanakan ialah terjadi peningkatan hasil belajar dari siklus I ke sikluas II dimana nilai rata-rata pada pre-test sebesar 16,81\%, kemudian pada siklus I meningkatkan menjadi 35,36\%, selanjutnya pada pre-test untuk siklus II sebesar 63,26\% dan meningkat menjadi 83,97\%. Sementara untuk Ranah Afektif siklus I hanya mencapai 65,83\% dan meningkat menjadi 85,34\% pada siklus II. Begitu juga untuk ranah Psikomotorik pada siklus hanya mencapai 66,39 dan meningkat menjadi 85,95\%. Dari hasil penelitian ini dapat disimpulkan bahwa dengan menggunakan Model Pembelajaran Kooperatif Student Facilitator and Eksplaining (SFAE) ternyata dapat meningkatkan hasil belajar instalasi jaringan.
\end{abstract}

Keywords: Model Pembalajaran, Student Facilitator and Eksplaining, Instalasi Jaringan.

\section{PENDAHULUAN}

\section{A. Latar Belakang}

Undang-undang Nomor 20 Tahun 2003 Tentang Sistem Pendidikan Nasional (Sudjana, 2005:2) menyatakan Pendidikan adalah usaha sadar dan terencana untuk mewujudkan suasana belajar dan proses pembelajaran agar peserta didik secara aktif mengembangkan potensi dirinya untuk memiliki kekuatan spiritual keagamaan, pengendalian diri, kepribadian, kecerdasan, akhlak mulia, serta keterampilan yang diperlukan dirinya, masyarakat, bangsa dan negara.

Seiring dengan perkembangan zaman yang semakin maju maka manusia dituntut untuk menguasai ilmu pengetahuan dan teknologi. Ilmu pengetahuan hanya bisa diperoleh melalui pendidikan, baik pendidikan formal maupun pendidikan informal (Depdikbud. 2003).

Keberhasilan belajar ditandai adanya perubahan-perubahan pada diri Peserta didik menjadi lebih baik. Perubahan itu antara lain perubahan pola pikir, perasaan, pemahaman, dan tingkah laku secara umum. Keberhasilan belajar Peserta didik dipengaruhi oleh beberapa faktor, antara lain: intelegensi, minat, bakat, keadaan sosial ekonomi, perhatian orang tua, metode mengajar, media, kurikulum, kesiapan, dan teman bergaul (Slameto, 2003).

kompetensi siswa dalam belajar memuat tiga ranah atau aspek dasar yaitu : kognitif, efektif dan psikomotorik.
Ranah ini memiliki karakterisktik tersendiri yang dapat diukur dalam proses pembelajaran yakni kognitif meliputi: pengetahuan, pemahaman, aplikasi, analisis, sintesis dan evaluasi. Ranah efektif yakni: menerima, menanggapi, menilai, mengorganisasi dan membentuk watak, Sedangkan psikomotorik dicirikan sebagai berikut: meniru, menyusun, melakukan dengan sesuai prosedur, melakukan dengan baik dan tepat, dan melakukan tindakan secara alami (Arikunto, 2007).

Namun, pada kenyataannya pembelajaran yang ada di sekolah saat ini masih belum sesuai dengan harapan. Seperti yang diperoleh dari hasil observasi di kelas X pada SMK Negeri 8 jeneponto diperoleh hasil yang berbeda. Guru masih mengalami kesulitan dalam menyelenggarakan pembelajaran yang efektif, karena masih menggunakan pembelajaran konvensional khususnya Teknik Instalasi Jaringan. Disamping itu kecendrungan peserta didik yang masih kurang antusias dan peserta didik terkadang menganggap pembelajaran Konvensional itu kurang menarik sehingga peserta didik terkadang tidak menyimak secara seksama materi yang disampaikan, atau dengan kata lain peserta didik masih kurang aktif dalam proses pembelajaran sehingga hasil belajarnya masih kurang. Akibatnya berdampak pada perolehan nilai hasil belajar Peserta didik. Hasil dokumentasi yang dilakukan di SMK 
Negeri 8 jeneponto, menunjukkan hasil belajar Peserta didik secara umum masih sangat kurang. Nilai rata-rata Teknik Instalasi Jaringan Peserta didik di SMK Negeri 8 Jeneponto pada ulangan tengah semester I tahun pelajaran 2018/2019 adalah 65. Sementara itu, kriteria ketuntasan minimal untuk mata pelajaran Teknik Instalasi Jaringan adalah 75 .

Berdasarkan hasil observasi tersebut, tampak bahwa rata-rata nilai peserta didik masih di bawah kriteria ketuntasan minimal yang harus dicapai oleh Peserta didik. Berdasarkan hasil observasi yang telah dilakukan diperoleh bahwa ketika proses pembelajaran Pendidiklah yang aktif (teacher centered) berperan dalam proses pembelajaran, sedangkan Peserta didik hanya sebagai pendengar yang pasif dan kadang-kadang aktif dalam proses pembelajaran. Selain itu, pembelajaran Teknik Instalasi Jaringan masih menekankan pada konsep-konsep yang terdapat di dalam buku. Hal ini disebabkan oleh kekurangtepatan pendidik di dalam menerapkan model, metode, teknik, dan strategi pembelajaan pada saat pelajaran Teknik Instalasi Jaringan berlangsung. Pada saat proses pembelajaran berlangsung pendidik tidak menerapkan teknik yang sesuai dengan kebutuhan Peserta didik salah satunya tidak menampilkan alat peraga sebagai alat bantu pembelajaran, sehingga anak mudah jenuh dan tidak tertarik mengikuti proses pembelajaran. Padahal ada alat peraga yang ada disekolah yang dapat digunakan oleh guru untuk membantu proses pembelajaran Teknik Instalasi Jaringan, agar lebih efektif.

Salah satu alternatif untuk mengatasi masalah yang ada berupa penerapan model pembelajaran yang lebih mengutamakan keaktifan Peserta didik dan memberikan kesempatan kepada Peserta didik untuk mengembangkan potensi secara maksimal. Model pembelajaran yang dimaksud yaitu pembelajaran kooperatif. Menurut Davidson dan Warsham (dalam Isjoni, 2011) Pembelajaran kooperatif adalah model pembelajaran yang mengelompokkan siswa untuk tujuan menciptakan pendekatan pembelajaran yang berefektifitas yang mengintegrasikan keterampilan sosial yang bermuatan akademik.

Slavin (dalam Isjoni, 2011) menyatakan bahwa pembelajaran kooperatif adalah suatu model pembelajaran dimana siswa belajar dan bekerja sama dalam kelompok-kelompok kecil secara kolaboratif yang anggotanya terdiri dari 4-6 orang dengan struktur kelompok heterogen. Jadi dalam model pembelajaran kooperatif ini, siswa bekerja sama dengan kelompoknya untuk menyelesaikan suatu permasalahan. Dengan begitu siswa akan bertanggung jawab atas belajarnya sendiri dan berusaha menemukan informasi untuk menjawab pertanyaan-pertanyaan yang diberikan pada mereka. Berdasarkan uraian di atas, dapat disimpulkan bahwa model pembelajaran kooperatif adalah model pembelajaran yang mengutamakan pembentukan kelompok yang bertujuan untuk menciptakan pendekatan pembelajaran yang efektif.

Dalam pembelajaran kooperatif terdapat berbagai tipe pembelajaran, salah satu diantaranya yaitu Student Facilitator and Explaining. Model Pembelajaran Student Facilitator and Explaining merupakan model pembelajaran dimana peserta didik belajar mempresentasikan ide/pendapat pada rekan peserta didik lainnya. Model pembelajaran ini efektif untuk melatih peserta didik berbicara untuk menyampaikan ide/gagasan atau pendapatnya sendiri. (Santoso, 2011).

Berbagai uji coba telah dilakukan pada penelitian sebelumnya, salah satu nya penelitian yang dilakukan oleh Mika adi Santa (2013) melakukan penelitian tentang Pengaruh model pembelajaran Kooperatif student facilitator and Explaining terhadap prestasi belajar matematika siswa Kelas v semester II SD negeri 2 gianyar. Hasil penilitian menunjukkan bahwa dengan menggunakan Model Pembelajaran Kooperatif Student Facilitator And Explaining menunjukan perubahan pada setiap peserta didik ditandai dengan meningkatnya prestasi belajar siswa. Hal ini dapat dilihat dari skor tes siswa pada setiap akhir siklus dan aktivitas belajar siswa yang ditunjukkan pada proses belajar mengajar.

Penelitian yang sama dilakukan oleh Agustina (2011) yang Melakukan penelitian tentang Penerapan model pembelajaran Kooperatife tipe student Facilitator And Eksplaining telah terbukti efektif dalam meningkatkan hasil belajar siswa dan terbukti signifikan dimana peningkatan tersebut terlihat dalam setiap siklus belajar. Keunggulan model pembelajaran Student Facilitator And Eksplaining juga ditunjukkan oleh ketuntasan belajar siswa yang mengalami peningkatan.

Oleh sebab itu, Penelitian ini bertujuan untuk mengetahui besarnya peningkatan hasil belajar Peserta didik kelas X pada jurusan Teknik Komputer dan Jaringan pada mata pelajaran teknik instalasi Jaringan di SMK Negeri 8 Jeneponto dengan menggunakan Model pembelajaran Kooperatif Student Facilitator And Explaining (SFAE).

\section{METODE PENELITIAN}

Penelitian ini adalah penelitian tindakan kelas (classroom action research). Penelitian tindakan kelas yang khusus dimaksudkan untuk memperbaiki dan meningkatkan kualitas pembelajaran. Penelitian tindakan kelas bukan penelitian eksperimen, dan bukan penelitian pengembangan. Oleh karena itu, masalahnya ialah bagaimana meningkatkan kualitas pembelajaran dan peningkatan hasil belajar dengan menggunakan metode, strategi, atau model pembelajaran tertentu. Rumusan masalah itu dijawab dengan bukti-bukti, proses dan hasil tindakan yang dilakukan. Penelitian Tindakan Kelas ini 
dilakukan secara bersiklus. Setiap siklus terdiri atas 4 tahap yaitu: (1) perencanaan, (2) tindakan, (3) observasi dan evaluasi, (4) refleksi.

Prosedur penelitian tindakan kelas ini dirancang dua siklus. Tiap siklus dilaksanakan sesuai dengan perubahan yang ingin dicapai. Setiap siklus berlangsung selama 4 kali pertemuan, dan disetiap siklus pada pertemuan pertama sebelum pembelajaran dilakukan tes evaluasi begitu juga pada setiap akhir siklus dilakukan tes evaluasi, hal ini bertujuan untuk mengetahui perkembangan hasil belajar peserta didik setiap siklus.

Kemmis \& Mc Taggart (dalam Tukiran Tunireja, 2010: 24): Rancangan penelitian ini mengikuti model Kemmis dan Mc Taggart yang terdiri dari empat komponen utama, yaitu (1) rencana, (2) tindakan, (3) observasi, dan (4) refleksi. Model ini dapat digambarkan sebagai berikut:

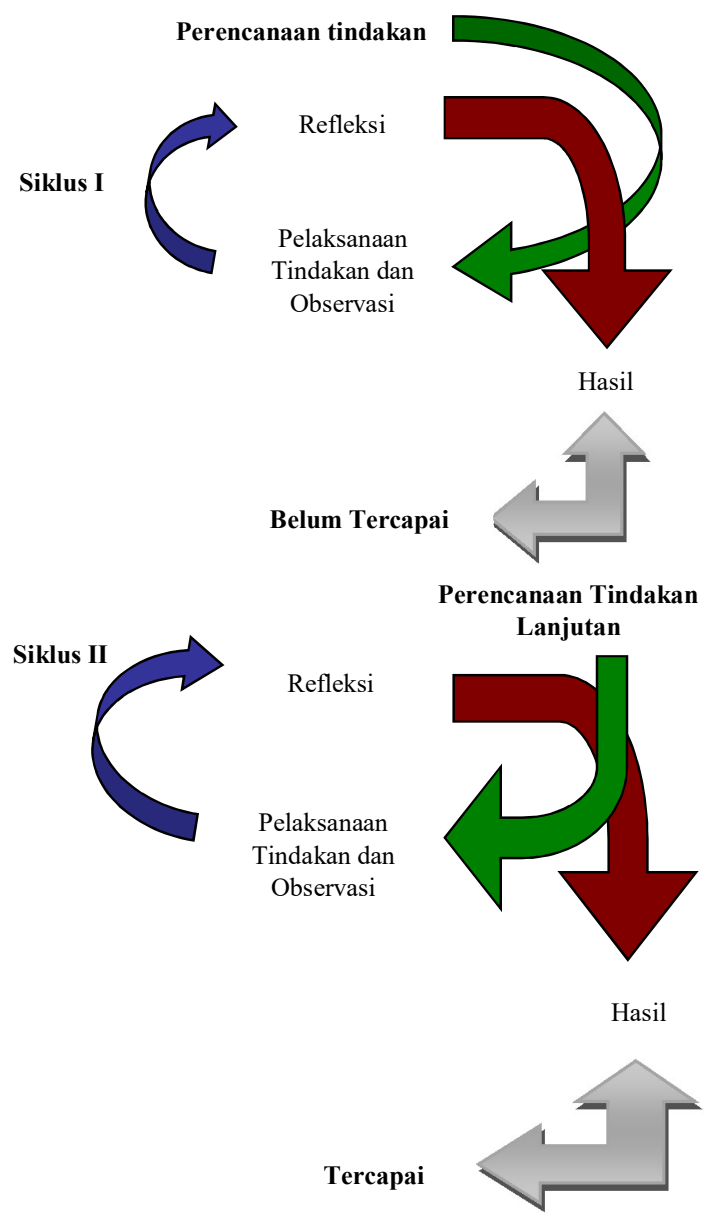

Gambar 2.1 .Model Penelitian Tindakan Kelas

\section{HASIL DAN PEMBAHASAN}

\section{Deskripsi Penerapan Model Pembelajaran Kooperatif Student Facilitator and Expalaining (SFAE).}

Penelitian Tindakan Kelas (PTK) pada Mata Pelajaran Teknik Instalasi Jaringan dengan menerapkan Model Pembelajaran Kooperatif Student Facilitator and Explaining (SFAE) kelas X dilakukan secara kolaboratif antara peneliti dengan guru mata pelajaran, yaitu peneliti sebagai pendidik dan guru sebagai pengamat. Penelitian tindakan kelas dilaksanakan dalam dua siklus, siklus I dan siklus II. Siklus I membahas tentang Pengenalan Dasar Jaringan Komputer. Siklus II membahas tentang Instalasi kabel Straight dan Cross. siklusnya terdiri dari tahap perencanaan, pelaksanaan, pengamatan dan refleksi.

Pelaksanaan pembelajaran dengan Model Pembelajaran Kooperatif Student Facilitator and Explaining (SFAE) mengacu pada silabus sekolah, namun RPP di susun sendiri oleh peneliti. Pelaksanaan pembelajaran ini juga ditunjang dengan adanya soal evaluasi untuk mengetahui sejauh mana pemahaman siswa yang berbentuk obyektif tes, serta lembar observasi afektif dan psikomotorik.

Proses pembelajaran dengan Model Pembelajaran Kooperatif Student Facilitator and Explaining (SFAE) diawali dengan salam, mengecek kehadiran peserta didik dengan peserta didik sudah duduk sesuai dengan kelompoknya sebelum pembelajaran dimulai. Kemudian pendidik memulai dengan bertanya tentang materi pelajaran yang telah dipelajari di pertemuan sebelumnya serta memberi motivasi kepada peserta didik dan tidak lupa juga pendidik menyampaikan tujuan pembelajaran.

Kegiatan inti pendidik menyajikan materi kepada peserta didik dimulai dengan melakukan apersepsi kepada peserta didik dengan mengajukan pertanyaan tentang materi yang sudah didapat pada pertemuan sebelumnya yang berhubungan dengan materi yang akan dibahas. Kemudian pendidik menyajikan materi. Setelah selesai penyampaian materi, pengajar meminta kepada peserta didik untuk berdiskusi membuat bagan/peta konsep sesuai dengan sub pokok bahasan materi yang di pelajari. Sebelum siswa berdiskusi pendidik memberi motivasi kepada semua peserta didik untuk ikut aktif dalam tugas kelompok, karena peserta didik akan ditunjuk secara acak untuk presentasi dan diberi pertanyaan oleh pendidik. Sehingga jika mereka tidak serius dan tidak bisa menjawab pertanyaan maka akan dikurangi nilainya. Bagi yang aktif tanpa pendidik yang meminta dan bisa menjawab pertanyaan maka akan ditambah nilainya. Pada siklus II siswa sudah dapat beradaptasi dengan Model Pembelajaran Kooperatif Student Facilitator and Explaining (SFAE), sehingga pendidik tidak perlu memberikan arahan lagi dan tidak perlu membimbing secara khusus, hanya saja jika ada peserta didik yang gaduh dan pasif pendidik menegur dan 
memotivasi. Salah satu peserta didik mewakili kelompoknya menyampaikan hasil diskusi dengan presentasi di depan kelas, sedangkan kelompok lain memperhatikan serta memberikan tanggapan berupa pertanyaan atau sanggahan. Kelompok yang melakukan presentasi menanggapi dengan menjawab pertanyaan kelompok yang tidak presentasi. pada siklus II peserta didik tidak perlu ditunjuk untuk presentasi, mereka secara sukarelawan maju kedepan. Selain itu peserta didik banyak yang aktif bertanya. Pendidik menyimpulkan hasil presentasi kemudian menjelaskan semua materi secara garis besarnya agar peserta didik lebih memahami materi yang dipelajarinya.

Pada kegiatan penutup yaitu di akhir siklus pendidik meminta peserta didik mengumpulakn tugas pada pertemuan sebelumnya dan menutup pelajaran. Kemudian pendidik memberikan tes evaluasi kognitif terhadap siswa.

Pelaksanaan pembelajaran dengan Model Pembelajaran kooperatif Student Facilitator and Explaining (SFAE) dengan langkah-langkah tersebut dapat meningkatkan hasil belajar, karena peserta didik terlibat secara langsung dalam proses pembelajaran. Pembelajaran dengan model tersebut juga melatih peserta didik mengungkapkan idenya melatih keberanian berbicara didepan teman-temannya. Kemudian adanya diskusi dalam kelompok dan tanya jawab ketika presentasi, terjadi proses pertukaran pikiran hal itu membuat siswa yang kurang paham menjadi paham, yang tidak tahu menjadi tahu. Hal itu sesuai dengan yang disamapikan Devira (2012) Model Student Facilitator and Explaining merupakan suatu model yang memberikan kesempatan kepada siswa atau peserta untuk mempresentasikan ide atau pendapat pada rekan peserta lainnya.

\section{A. Hasil Belajar Ranah Kognitif}

Hasil Analisis Uji gain untuk melihat Peningkatan nilai rata-rata hasil belajar siswa pada pre-test, tes akhir siklus I dan tes akhirr siklus II dapat dilihat pada Tabel 3.1.

Tabel 3.1

Hasil belajar ranah Kognitif

\begin{tabular}{|c|c|c|c|c|c|}
\hline & Keterangan & SIKI & JS 1 & SIKI & JS II \\
\hline & Nilai Terendah & 3 & 13 & 13 & 77 \\
\hline & Nilai Tertinggi & 27 & 90 & 93 & 97 \\
\hline$\cdot \frac{\pi}{n}$ & Rata-Rata Kelas & 16.81 & 35.36 & 63.26 & 83.97 \\
\hline 宗 & Ketuntasan Klasikal & 0 & 36.6 & 60 & 97 \\
\hline & $\begin{array}{c}\text { Gain Score Siklus I } \\
\text { ke Siklus II }\end{array}$ & & & & \\
\hline & Kriteria Peningkatan & & & & \\
\hline
\end{tabular}

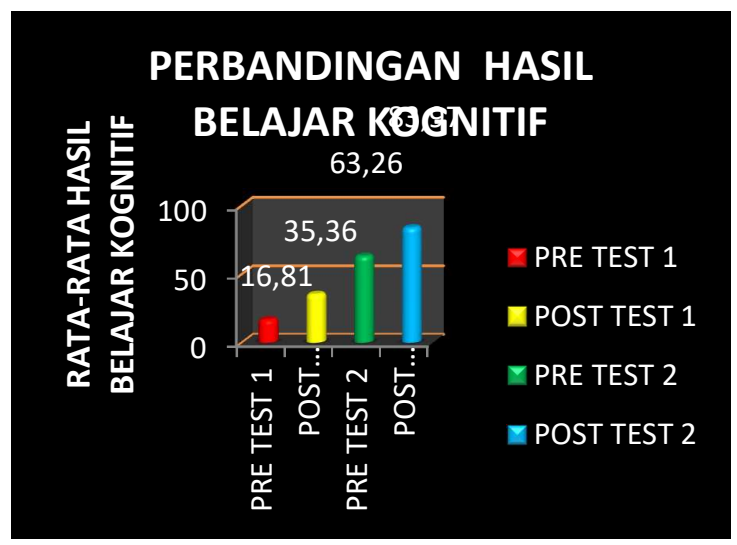

Gambar 4.5.

Perbandingan Hasil Belajar Kognitif

Sebelum dilakukan tindakan dalam penilitian ini, kemampuan awal siswa diukur dengan pemberian pre-test sehingga diperoleh nilai rata-rata sebesar $16,81 \%$. Penelitian memberikan pre-test pada peserta didik untuk mengatahui tingkat pemahaman peserta didik sebelum diterapkan model pembelajaran Kooperatif Student Facilitator And Eksplaining (SFAE) dalam proses pembelajaran. Setelah dilakukan tindakan dengan menerapkan model pembelajaran Kooperatif Student Facilitator And Eksplaining (SFAE dalam proses pembelajaran, terjadi peningkatan nilai rata-rata pada siklus I sebesar $35,36 \%$ dan nilai peserta didik pada pemberian soal pre-test sebelum siklus II dilakukan sebesar $63,26 \%$ serta terjadi peningkatan pada tes akhir siklus II sebesar 83,97 .

Pada dasarnya tindakan yang dilakukan pada siklus I sama dengan tindakan yang dilakukan pada siklus II, hanya saja pada siklus II telah dilakukan beberapa perbaikan dan penambahan sesuai dengan hasil refleksi pada siklus I. Berdasarkan Tabel 3.1 dan Gambar 3.1 hasil belajar kognitif mengalami peningkatan dari siklus I ke siklus II, walaupun pada pre test 1 dan post test 1 belum bisa dikatakan tuntas, akan tetapi jika di perhatikan dengan baik hasil belajar peserta didik meningkat setiap melakukan evaluasi dan sudah memenuhi kriteria ketuntasan pada siklus II.

\section{B. Hasil Belajar Ranah Afektif}

Penilaian hasil belajar afektif meliputi tanggung jawab peserta didk, kemandirian, menjadi pendengar yang baik, menghargai pendapat orang lain dan keberanian menyampaikan pendapat. Hasil analisis ranah afektif peserta didik pada siklus I dan siklus II (data dimuat di lampiran 19) dapat dilihat pada Tabel 3.2. 


\begin{tabular}{|c|l|c|c|}
\hline \multirow{2}{*}{} & Keterangan & Cukup & Sangat tinngi \\
\cline { 2 - 4 } & Nilai Terendah & 25 & 75 \\
\cline { 2 - 4 } & Nilai Tertinggi & 95 & 100 \\
\cline { 2 - 4 } & Rata-Rata Kelas & 65.83 & 85.34 \\
\cline { 2 - 3 } & Ketuntasan Klasikal & 58.62 & 100 \\
\cline { 2 - 4 } & $\begin{array}{l}\text { Gain Score Siklus I } \\
\text { ke Siklus II }\end{array}$ & \multicolumn{2}{|c|}{0.6} \\
\cline { 2 - 4 } & Kriteria Peningkatan & \multicolumn{2}{|c|}{ Sedang } \\
\hline
\end{tabular}

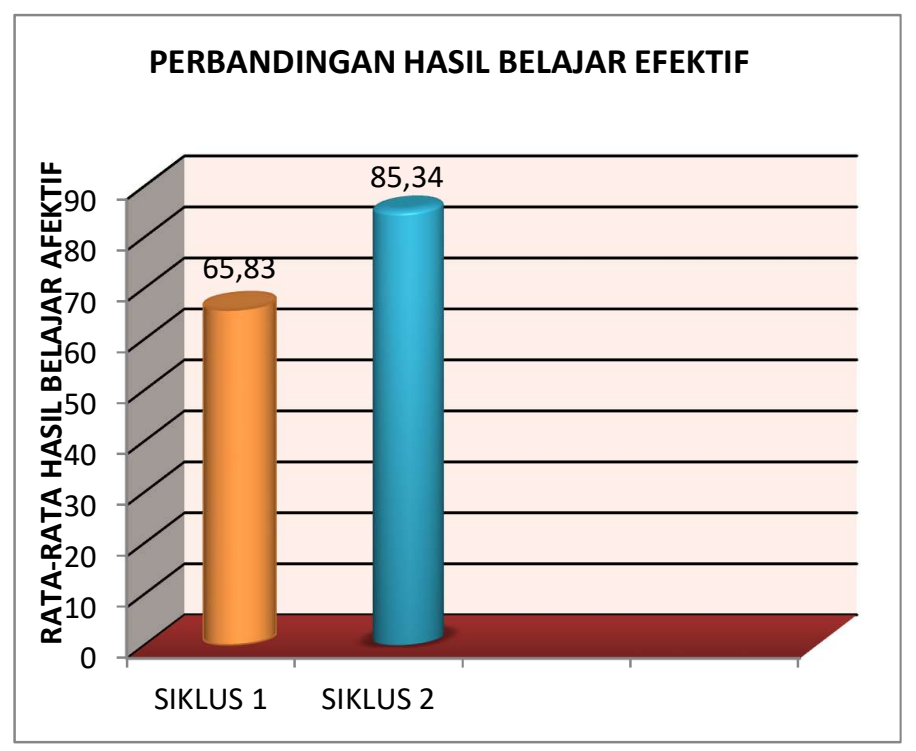

Gambar 3.2.

Perbandingan Hasil Belajar Kognitif

Berdasarkan Tabel 4.10 dan Gambar 4.6 hasil belajar afektif mengalami peningkatan dari siklus I ke siklus II. Dari diagram diatas terlihat bahwa hasil belajar efektif pada siklus 1 hanya mencapai 65,83 \% dan pada siklus 2 meningkat menjadi 85,34\%. Peningkatan hasil belajar afektif ini terjadi karena peserta didik terlibat secara langsung dalam pembelajaran dengan penerapan Model Pembelajaran Student Facilitator and Explaining.
Peserta didik tertarik untuk mengikuti pembelajaran. Karena dengan berkelompok peserta didik saling bertukar pendapat dengan peserta didik yang lain, mandiri, bertanggung jawab, Selain itu keberhasilan kelompok ditentukan oleh kerjasama dari masing-masing peserta didik dalam satu kelompok. Jika ada peserta didik yang tidak bertanggung jawab, tidak berani menyampaikan pendapat dan tidak menghargai pandapat orang lain maka ada kemungkinan hasil diskusinya kurang baik.

Pada siklus I hasil belajar untuk ranah efektif sudah dikatakan memenuhi kriteria ketuntasan. Akan tetapi walau begitu tetap memiliki kekurangan, ketika proses pembelajaran berlangsung ada beberapa peserta didik yang berbicara sendiri dan membuat gaduh. Selain itu ada peserta didik yang berpangku tangan kepada peserta didik yang lain. Oleh karena itu pada siklus II diperbaiki dengan memberi teguran dan motivasi berupa penghargaan berupa tambahan nilai bagi kelompok yang kompak dan hasil kerjanya bagus dengan menyampaikan bahwa berhasil/tidaknya kelompok tergantung dari anggotanya. Menjelaskan kepada peserta didik bahwa jika mereka tidak meperhatikan dan tidak mengikuti jalannya diskusi maka mereka tidak akan menguasai materi yang nantinya tidak dapat menjawab pertanyaan. Sehingga pada siklus II dapat meningkatkan hasil belajar.

Peningkatan hasil belajar afektif yang dianalisis dengan uji gain menunjukkan bahwa peningkatannya dalam kriteria sedang. Hal tersebut dikarenakan siswa yang belum terbiasa dengan Model Pembelajaran Student Facilitator and Explaining (SFAE) serta ada beberapa siswa yang masih membuat gaduh dan kurang menjadi pendengar yang baik.

\section{Hasil Belajar Ranah psikomotorik}

Penilaian hasil belajar psikomotorik meliputi aktif dalam diskusi, membuat pertanyaan yang kreatif, cepat menyelesaikan praktikum. Hasil belajar ranah psikomotorik siswa pada siklus I dan siklus II (data dimuat di lampiran 25) dapat dilihat pada Tabel 4.11.

Tabel 4.11.

Hasil belajar Ranah Psikomotorik

\begin{tabular}{|c|c|c|c|}
\hline \multirow{4}{*}{$\frac{\sqrt[n]{\mathscr{N}}}{\frac{.}{3}}$} & Keterangan & Cukup & $\begin{array}{l}\text { Sangat } \\
\text { tinngi }\end{array}$ \\
\hline & Nilai Terendah & 25 & 75 \\
\hline & Nilai Tertinggi & 91.7 & 100 \\
\hline & Rata-Rata Kelas & 66.39 & 85.92 \\
\hline
\end{tabular}




\begin{tabular}{|l|l|c|c|}
\hline & Ketuntasan Klasikal & 65.52 & 100 \\
\cline { 2 - 3 } $\begin{array}{l}\text { Gain Score Siklus I } \\
\text { ke Siklus II }\end{array}$ & \multicolumn{2}{|c|}{0.58} \\
\hline Kriteria & \multicolumn{2}{|c|}{ Sedang } \\
Peningkatan & \\
\hline
\end{tabular}

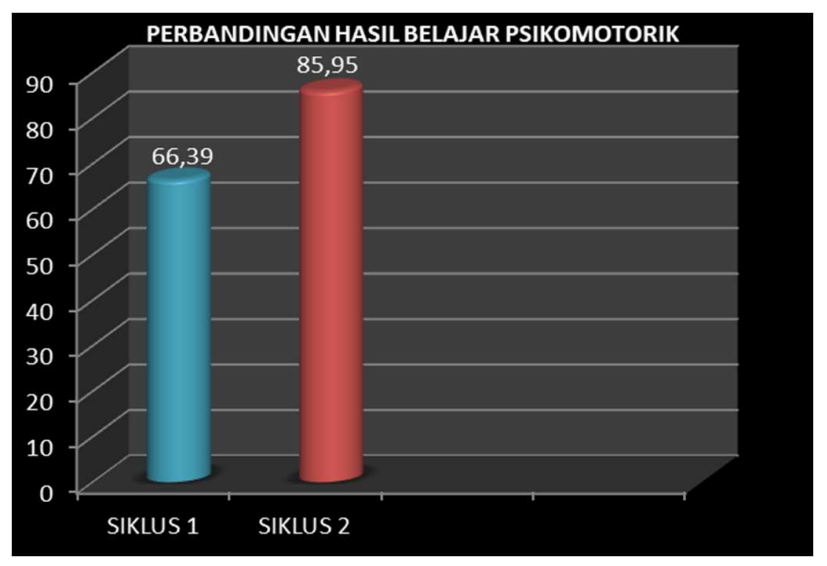

Gambar 4.7.

Diagram Batang Hasil Belajar psikomotorik

Berdasarkan Tabel 4.11 dan Gambar 4.7 hasil belajar psikomotorik pada siklus I mencapai $66,39 \%$ sedangkan pada siklus II meningkat menjadi $85,95 \%$. Peningkatan hasil belajar psikomotorik ini terjadi karena peserta didik dituntut untuk aktif dalam diskusi dan peserta didik juga di tuntut untuk mampu membuat pertanyaan yang kreatif dalam diskusi serta di tuntut untuk mampu menyelesaikan setiap praktikum dengan cepat dan tepat.

Pada siklus I hasil belajar belum bisa dikatakan berhasil karena belum memenuhi kriteria ketuntasan. Hal tersebut dikarenakan pada saat pelaksanaan pembelajaran ada beberapa peserta didik yang pasif, karena peserta didik merasa tidak bisa dan berpangku tangan pada peserta didik lain dalam satu kelompok. Ketika presentasi tidak ada peserta didik yang mau maju karena malu, sehingga pengajar harus menujuk salah satu dari murid. Ketika ditunjuk peserta didik tetap menolak karena takut ditertawakan atau dimarahi jika salah, akhirnya dengan arahan dari pendidik peserta didik bersedia maju. peserta didik sedikit yang bertanya dan banyak yang tidak bisa menjawab pertanyaan, hal itu karena mereka belum terbiasa dengan Model Pembelajaran Student Facilitator and Expalining (SFAE).

Pada siklus II pendidik memberi arahan bahwa peserta didik yang akan presentasi dan yang akan diberi pertanyaan oleh pengajar akan dipilih secara acak. Bagi peserta didik yang tidak aktif dalam diskusi dan tidak serius dalam pembelajaran, tidak akan mampu presentasi dan menjawab pertanyaan ketika ditunjuk oleh pendidik karena tidak menguasai materi. Bagi peserta didik yang berlaku seperti itu akan dikurangi nilainya dan bagi yang aktif dan mampu membuat pertanyaan maupun menjawab pertanyaan akan ditambah nilainya. Sehingga menjadikan peserta didik berusaha untuk aktif dan berusaha menguasai materi karena merasa takut jika tidak bisa ketika ditunjuk. Akan tetapi ketika disuruh presentasi peserta didik tetap malu-malu untuk maju, takut jika salah. Pengajar memotivasi dengan memberi penghargaan berupa nilai bagi yang presentasi maupun yang bertanya, peserta didik tetap masih tidak mau maju sehingga pengajar memotivasi kepada peserta didik bahwa mereka pasti bisa, tidak akan ditertawakan dan tidak akan dimarahi, peserta didik yang lain juga belum tantu paham, dan bisa jadi mereka salah satu dari yang paham dan bisa berbagi ilmu dengan teman sekelas sehingga peserta didik yang lain ikut menjadi paham. Dari hal itulah akhirnya ada beberapa siswa yang mau maju tanpa ditunjuk oleh pengajar dan banyak yang aktif bertanya. Sehingga pada siklus II hasil belajar psikomotorik dapat memenuhi kriteria ketuntasan.

Peningkatan hasil belajar psikomotorik yang dianalisis dengan uji gain menunjukkan bahwa peningkatannya dalam kriteria sedang. Hal tersebut dikarenakan siswa yang belum terbiasa dengan Model Pembelajaran Student Facilitator and Explaining (SFAE) serta ada beberapa siswa yang kurang bisa menjawab pertanyaan dan hanya bisa membuat pertanyaan yang kurang kreatif terlebih lagi di praktek karena itu sesuatu yang baru dan waktu untuk praktek yang kurang mencukupi.

\section{KESIMPULAN}

Berdasarkan hasil penelitian dan pembahasan yang telah dilakukakan maka, dpat disimpulkan bahwa; (1) Penggunaan Model Pembelajaran Kooperatif Student Facilitator And Eksplaining (SFAE) ternyata dapat meningkatkan hasil belajar kelas X TKJ Di SMK Negeri 8 Jeneponto, baik dari Kognitif peserta didik, Afektif maupun Psikomotorik peserta didik; (2) Peningkatan hasil belajar peserta didik dapat dilihat pada pemberian soal pretest 1 yaitu sebesar $16,81 \%$ kemudian hasil post-test pada siklus I meningkat menjadi $35,36 \%$, selanjutnya pada pemberian soal pre-test 2 untuk siklus II sebesar $63,26 \%$ kemudian meningkat menjadi $83,97 \%$ disiklus II. Hal ini menunjukkan bahwa peningkatan hasil belajar peserta didik terjadi secara berkala; (3) Hasil belajar untuk ranah afektif dan psikomotorik juga mengalami peningkatan, untuk ranah afektif pada siklus 1 hanya mencapai sampai 65,83\% kemuadian meningkat menjadi $85,34 \%$ pada siklus 2 . Begitu juga untuk Ranah Psikomotorik, pada siklus 1 hanya mampu mencapai sampai 66,39\% kemudian meningkat menjadi $85,95 \%$. Hal ini menunjukkan bahwa Hasil belajar untuk ranah Afektif dan psikomotorik juga meningkat. 
Jurnal MediaTIK : Jurnal Media Pendidikan Teknik Informatika dan Komputer

Vol.3 No.2 (Mei 2020)

\section{DAFTAR PUSTAKA}

[1] Agustina. Wuri. 2011. Penerapan Model Pembelajaran Student Facilitator and Explaining (SFAE) Pada Mata Pelajaran IPS Sub Mata Pelajaran Ekonomi Untuk Meningkatkan Hasil Belajar Siswa Kelas VIII SMP Negeri 17 Malang. Malang: Jurnal UM (http://library.um.ac.id/ptk/index.php?mod=detail\&id=49717).

[2] Arikunto, Suharsimi. 2006. Dasar-Dasar Evaluasi Pendidikan. Jakarta: PT Rineka Cipta.

[3] Anas, Sudjono. 2011. Pengantar Evaluasi Pendidikan. PT Rajawali Grafindo Persada. Jakarta.

[4] Depdikbud. 2003. Kamus Besar Bahasa Indonesia. Balai Pustaka. Jakarta.

[5] Djamarah, Bakri. 1995. Strategi Belajar Mengajar. PT. Rineka Cipta. Jakarta.

[6] Davidson, dkk. 2011. Dalam buku isjoni. Rineka Cipta. Jakarta.

[7] Slameto, 2003. Belajar dan Faktor-Faktor yang Mempengaruhinya. Rineka Cipta. Jakarta.

[8] Slavin, 2011. Dalam buku isjoni. Rineka Cipta. Jakarta.

[9] Sudjana,Nana. 2006. Penilaian Hasil Proses Belajar Mengajar. Bandung: PT. Remaja Rosdakarya.

[10] Undang-undang Nomor 20 Tahun 2003 Tentang Sistem Pendidikan Nasional. 